\title{
Social Security Status and Retirement Planning of Salaried Class Investors: A Study of Haryana State
}

\author{
Anita Taneja, Ph.D. Research Scholar, Lovely Professional University, Phagwara, Punjab ${ }^{\mathrm{a}}$ \\ Dr. Mahesh Kumar Sarva, Associate Professor, Lovely Professional University, Phagwara, Punjab ${ }^{\text {b }}$
}

\begin{abstract}
:
Social security becomes the emergent issue of the world. For developing countries, it is very difficult to provide the social security to whole population but it is very important for the welfare for entire society. In all phases of life, social and economic security is necessary but need of security is increased in the old age because human not remains so efficient to do the work and they have no regular source of income in this phase of life. Main aim of this paper is to find the relationship between the demographic variables and social security conditions and retirement planning of salaried class investors of Haryana state. Total 150 is the sample size. The data is collected through a well structured questionnaire for salaried class investors of Haryana state. Main finding of this paper is salaried class investors have same level of social security conditions on the basis of different demographical variables such as gender, age, marital status, nature of employment, job experience, annual income and number of dependent family members except some statements but age is significant towards the retirement planning except some statements.
\end{abstract}

Keywords: Social Security, Retirement Planning, Haryana,

Article Received: 18 October 2020, Revised: 3 November 2020, Accepted: 24 December 2020

\section{Introduction:}

Nowadays social security becomes the emergent issue of the world. Providing social security to the population in developing countries becomes more difficult than the developed countries because developing countries are facing the vital problems like inequality of wealth distribution, poverty, slow improvement in rate of capital formation, poor quality of human capital, unemployment, poor educational level etc. So, it is very challenging task to provide the social security with facing these problems. India is a one of the developing countries which is facing the same nature of problems. But social security is very necessary for the welfare of the entire society because Productivity and work capability is increased by providing health care, social services and income security. In all the phases of life, social and economic security is necessary but need of security is increased in the old age because human not remains so efficient to do the work and productivity goes down with the increase in the age. It becomes very difficult to survival in old age with the dignity due to the no regular sources of income in this phase of life. Dependency is increased on the other people of family and society in old age. To provide the social and economic security to live independently in old age, there are various pension plans are available in India. Some pension plans are operating by the government to provide the social and economic security to its employees and their family like old pension scheme and new pension scheme. Some pension plans are operating by government and private pension fund managers to provide the social security to those who are not covered under the existing pension system and people are working in the private organisations and self-employed. So, with the investment in this beneficial pension cum retirement plans, people can do plan for their future and secure their retirement life and live happily. The investment in the retirement plans depends on the saving behaviour of the population. In last few decades there has been a drastic change in the saving and investment pattern of the population of India. People are educated and much aware about their current needs and future requirements. They do make a balance between their current and future needs and save for their future. Social and economic security is the very closely related to the saving behaviour towards the future so this is the main theme for this paper to study the status of social security and behaviour of salaried class investors towards the retirement planning.

\section{Review of Literature:}


Ketkaew C. et.al. (2019) studied about the effect of expected income on wealth accumulation and retirement contribution of Thai wageworkers. Researcher's main objective is to find the main factors which effect the decision of saving for retirement and found that expected income, wealth accumulation, career status and health status were the main factors, effect the saving for retirement.

Thakur S.S. \& Jain S.C. (2017) studied about the retirement planning and social security concept in Indian context. The researcher described that the investors make mistakes while choosing the investment alternatives due to lack of knowledge. Various component of social security system are also described by the researcher such as employees' provident fund organization, civil service pensions, new pension scheme, pension plan of public sector enterprises, occupational pension plans, voluntary tax advantaged schemes, schemes for the unorganized sectors and through these social security schemes the investment is made into various asset classes such as direct equity investment, combination of equity and debts., public provident fund, bank fixed deposits, company fixed deposits, national saving certificate, Kisan Vikas Patra, employees' provident fund, mutual funds, life insurance, bonds, money market instruments, derivative instruments, gold investments, real estate investment, debt. Instruments and Indian depositary receipts. Under this study respondents were asked to determine their 9 preference toward their asset class. House rental income is the first preference of retirees because it assures inflation adjusted fixed income from rent received and real estate shifted to next generation. Pension fund annuity, public provident fund, employee provident fund and bank deposit are the next preference of investors. Gold jewellary, equity and national saving certificate and post office savings are ranked at medium preference; NPS is at lowest preferred asset class. The researcher concluded that there is no such social security system in India as western countries. The Indian central and state government also converted the defined benefit pension schemes to defined contribution pension schemes. The respondents do not prefer Atal Pension Yojna as an investment preference. The finding of the study has policy implementations, so government has to take further decision to maintain the benefits to investors.

Manoli D.S. \& Weber A. (2016) studied about the effects of the early retirement age on retirement decisions. Researcher done the study on the basis of social security reforms in Austria in 2000 to 2004 and found that when the early retirement age increases, the aged people remained for long time on their job.

Dinesh Bansilal Shendkar (2016) studied about the financial planning for retirement among the individuals within the age group of 25 years to 45 years in Pune city. The researcher concluded that various factors like social, economic, demographic and political are affected the retirement planning. Capital market is a key source of attraction for investors. The govt. initiative of NPS is not seen picking up pace to the desired level.

Charan Singh et. al. (2015) studied about the ageing in India. Need for universal pension and concluded that India has a limited pension system and does not cover the whole population of country. Approximately $70 \%$ of the working population is not socially secured security. The purpose of pension is to provide assistance of consumption, mitigation of longevity risks and reduction of poverty. The introduction of new scheme will enhance the welfare of both the present and future aged population. Universal pension scheme could be one of those adequate steps with its inherent goal of providing economic security and of wider reach to the elderly.

Sood D. \& Kaur N. (2015) studied about the saving habits, investment pattern and investment selection behavior of salaried class people of Chandigarh and found that most desired investment alternatives opted by Chandigarh people are bank deposit, LIC. Tax exemption benefit, good return and security are the main factors influencing the investment decision.

Mohd Fitri Mansor et. al. (2015) analyzed the relationship between the demographic factors towards retirement planning with the survey on 110 health workers and found that age, household income and education level are significantly related with retirement planning but gender is insignificant towards retirement planning.

Barrientos A. (2012) studied about the assessment of social pension programs in Asia. This study focused on three key parameters of social pensions: poverty reduction, incentives and budgets and links between Non-contributory to contributory pension schemes. Non-contributory and contributory pension programs require considerable care in maintaining contribution incentives. The researcher concluded that several policy options are available and they need to be considered carefully in the context of conditions. 
Haris A. and Said R. (2012) studied about status of social security wealth and decision of early retirement in public pension scheme. The researcher found that income effect is positive and substitution effect is negative of pension scheme. The final result of this study is that the current public pension scheme benefits are not sufficient to encourage the public sector employee to take early retirement.

C.A. Yogesh et. al., (2012) studied about the investment perspective of salaried people of private sector. Data is collected from respondents regarding the investment in different avenues, income's proportion for saving and investment, reasons for investment preferences of investment and satisfaction from the investment and concluded that male are much aware and have more proportionate of saving and investment than female. Male are clear about various investment avenues return.

Pandiyan and T. A. (2012) studied about the saving and investment attitude of salaried class of Cuddalore district. The researcher studied the opinion data with the seven dimensions of saving and investment like "secured life", "Avoiding Investment in Private Companies", "Lack of Guidelines to children about saving", "Tough Task but for future", "Creation of Saving Habits by Government", "Savings requires experience" and wrong investment decisions by many people. The researcher found that the respondents have high level of attitude about all the dimensions except "Tough task but good for future".

Swasdpeera P. \& Pandey I.M. (2012) studied about the determinants of personal saving of salaried individuals in Thailand and found that income, age, marital status, number of children and educational level have influencing the behaviour of salaried individuals who save for future is different from those who are not willing to save.

Salvador R. (2012) studied about future retirees' concerns regarding pension plans reforms and demographic factors that affect the retirement investment decisions and concluded that the three variables were statically significant which are college education, income level and enrolment in an employer sponsored retirement plan that influence the self-efficacy and financial literacy. Some recommendations were also given by the researcher that universal participation in some type of retirement plan and increasing public financial literacy beyond basic levels.
Bloom D.E. et. al.,(2010) studied about the ageing in India and economic security arrangements for the old age people to make arrangement, govt. of India and some Indian states started the various health and insurance programmes to provide the security to the old age people. The researcher found that formal sector employees are more socially secure than informal sector's workers and women are specially socially and economically insecure.

Chatterjee S. (2010) analysed the retirement savings of private and public sector employees with comparative dimension on the basis of demographical variables like 18 education, income and investment characteristics and found that people, who have sufficient income for the present consumption, invest more in retirement plans and some do investment to avail tax benefits. It is also found that financial education also very important to prepare retirement plan.

Chaudhuri A. \& Roy K. (2009) studied about Indian old age persons living arrangements with reference of gender. The data was taken from $52^{\text {nd }}$ round of National Sample Survey, conducted by the National Sample Survey Organisation (NSSO) of India. The researcher found that older women are willing to live alone than men even after controlling health status, economic independence, property ownership, demographics and socioeconomic characteristics. Physical immobility characteristics decreased the willingness to live with children and physical immobility increase the willingness to live with children special women. When they sons instead of daughters.

Bloom D.E. et.al., (2007) studied the demographical factors, social security system and saving. Demographical factors like age, income, working age, old age is taken and employed persons are including and agricultural workers, informal sector workers and employed in small firms are excluded and analysed the retirement benefits are available in the system like pay as you go and fully funded. The researcher found that age factor can affect the aggregate savings and behavioural effects are influenced by expected longevity. As person has a long life span, then working for long period and increased savings.

\section{Objectives of the Study:}

The main objective of this paper is to study the status of social security conditions and retirement behaviour of salaried class investors.

\section{Research Methodology:}

Population of the Study: 
Population of the study consists of salaries class investors of Haryana state.

\section{Data Collection Techniques:}

Primary and secondary data is used for the study. Primary data is collected through a well-structured questionnaire and secondary data is collected through the various published source like journals, books, newspapers, websites etc.

\section{Sampling Method:}

Purposive sampling method is used in this study.

This is the non-probability sampling method.

Data Analysis:

Table 1:Demographical Profile of Respondents:

\begin{tabular}{|c|c|c|c|}
\hline Particular & Category & No. of Respondents & Percentage \\
\hline \multirow[t]{3}{*}{ Gender } & Male & 79 & $53 \%$ \\
\hline & Female & 71 & $47 \%$ \\
\hline & Total & 150 & $100 \%$ \\
\hline \multirow[t]{6}{*}{ Age } & Upto 25 & 05 & $03 \%$ \\
\hline & $25-35$ & 61 & $41 \%$ \\
\hline & $35-45$ & 63 & $42 \%$ \\
\hline & $45-55$ & 13 & $09 \%$ \\
\hline & Above 55 & 08 & $05 \%$ \\
\hline & Total & 150 & $100 \%$ \\
\hline \multirow[t]{3}{*}{ Marital Status } & Married & 117 & $78 \%$ \\
\hline & Unmarried & 33 & $22 \%$ \\
\hline & Total & 150 & $100 \%$ \\
\hline \multirow[t]{3}{*}{ Nature of Employment } & Government & 120 & $80 \%$ \\
\hline & Private & 30 & $20 \%$ \\
\hline & Total & 150 & $100 \%$ \\
\hline \multirow[t]{6}{*}{ Job Experience } & Upto 10 Years & 90 & $60 \%$ \\
\hline & 10-15 Years & 33 & $22 \%$ \\
\hline & 15-20 Years & 14 & $09 \%$ \\
\hline & 20-25 Years & 03 & $02 \%$ \\
\hline & Above 25 Years & 10 & $07 \%$ \\
\hline & Total & 150 & $100 \%$ \\
\hline \multirow[t]{6}{*}{ Annual Income } & Upto 5 Lakh & 38 & $25 \%$ \\
\hline & 5-10 Lakh & 80 & $53 \%$ \\
\hline & 10-15 Lakh & 26 & $17 \%$ \\
\hline & 15-20 Lakh & 03 & $02 \%$ \\
\hline & Above 20 Lakh & 03 & $02 \%$ \\
\hline & Total & 150 & $100 \%$ \\
\hline \multirow{6}{*}{$\begin{array}{l}\text { Number of Dependent } \\
\text { Family Members }\end{array}$} & Nil & 15 & $10 \%$ \\
\hline & One & 16 & $11 \%$ \\
\hline & Two & 47 & $31 \%$ \\
\hline & Three & 47 & $31 \%$ \\
\hline & More than Three & 25 & $17 \%$ \\
\hline & Total & 150 & $100 \%$ \\
\hline
\end{tabular}

Source: Primary Data

Interpretation: Data is collected for total 150 respondents, out of which $53 \%$ is male and $47 \%$ is

\section{Sampling Size, Element and Area:}

For this study, sample size is 150 respondents, sampling element is salaried class investors of Haryana state.

\section{Techniques to Analyze the Data:}

To analyze the data, initially survey is conducted with the help of a questionnaire. ANOVA, and ttest is used to analyze the relationship between independent and dependent variables. For effective analysis and easy understanding, the data is tabulated. 
25 years, $41 \%$ belongs to $25-35$ years, $42 \%$ belongs to $35-45$ years, $09 \%$ belongs to $45-55$ years, and $05 \%$ belongs above 55 years age. $78 \%$ are married and $22 \%$ are unmarried respondents. $80 \%$ respondents are engaging in government job and remaining $20 \%$ are doing the private job. Further respondents are classified in five categories on the basis of working experience $60 \%$ respondents are covering under less 10 years, $22 \%$ are covering under $10-15$ years, $09 \%$ are covering under $15-20$ years, $02 \%$ are covering under $20-25$ years, and $07 \%$ are covering under above 25 years job experience. Respondents are classified in five categories on the basis of income also. $25 \%$ respondents have income less than 5 lakhs, $53 \%$ respondents have income between 5-10 lakh, $17 \%$ respondents have income between the 10-15 lakhs, $02 \%$ income has between the 15-20 lakhs, and 02\% has income more than 20 lakhs. Respondents are classified under various dependent family members. $10 \%$ respondents have no dependent family members, $11 \%$ respondents have one dependent family members, $31 \%$ have two dependent family members, $31 \%$ respondents have three dependent family members, and $17 \%$ respondents have more than three dependent family members.

Table 2: $\mathrm{t}$ - test Statistics for Gender to Social Security Conditions of Salaried Class Investors

\begin{tabular}{|c|c|c|c|c|c|c|c|c|c|}
\hline & & Male & & Fem: & & & & & \\
\hline & Variables & $\begin{array}{l}\text { Mea } \\
\text { n }\end{array}$ & S.D. & $\begin{array}{l}\text { Mea } \\
\text { n }\end{array}$ & S.D. & $\begin{array}{l}\text { t } \\
\text { Valu } \\
\text { e }\end{array}$ & $\begin{array}{l}\mathbf{P} \\
\text { Valu } \\
\text { e }\end{array}$ & $\begin{array}{l}\text { Stat } \\
\text { Sig. } \\
\text { (Yes/No } \\
\text { ) }\end{array}$ & $\begin{array}{l}\text { Accepte } \\
\text { d/ } \\
\text { Not } \\
\text { Accepte } \\
\text { d }\end{array}$ \\
\hline 1 & $\begin{array}{l}\text { Number of persons in my } \\
\text { family other than me save for } \\
\text { old age }\end{array}$ & $\begin{array}{l}2.04 \\
0\end{array}$ & $\begin{array}{l}0.96 \\
7\end{array}$ & $\begin{array}{l}2.58 \\
0\end{array}$ & $\begin{array}{l}1.10 \\
4\end{array}$ & 0.319 & 0.002 & Yes & $\begin{array}{l}\text { Not } \\
\text { Accepted }\end{array}$ \\
\hline 2 & $\begin{array}{l}\text { Percentage of saving that I do } \\
\text { from annual income for old age }\end{array}$ & $\begin{array}{l}2.47 \\
0\end{array}$ & $\begin{array}{l}1.16 \\
4\end{array}$ & $\begin{array}{l}2.13 \\
0\end{array}$ & $\begin{array}{l}1.18 \\
2\end{array}$ & 1.781 & 0.077 & No & Accept \\
\hline 3 & $\begin{array}{l}\text { I feel socially secure with } \\
\text { working/employment status of } \\
\text { spouse }\end{array}$ & $\begin{array}{l}3.80 \\
0\end{array}$ & $\begin{array}{l}1.05 \\
5\end{array}$ & $\begin{array}{l}3.79 \\
0\end{array}$ & $\begin{array}{l}1.10 \\
7\end{array}$ & 0.049 & 0.961 & No & Accept \\
\hline 4 & $\begin{array}{l}\text { I have enough property for the } \\
\text { survival in old age }\end{array}$ & $\begin{array}{l}2.87 \\
0\end{array}$ & $\begin{array}{l}1.13 \\
6\end{array}$ & $\begin{array}{l}3.07 \\
0\end{array}$ & $\begin{array}{l}1.08 \\
7\end{array}$ & 1.082 & 0.281 & No & Accept \\
\hline 5 & $\begin{array}{l}\text { My family members would help } \\
\text { during post retirement period }\end{array}$ & $\begin{array}{l}3.58 \\
0\end{array}$ & $\begin{array}{l}1.02 \\
0\end{array}$ & $\begin{array}{l}3.35 \\
0\end{array}$ & $\begin{array}{l}1.16 \\
0\end{array}$ & 1.293 & 0.198 & No & Accept \\
\hline 6 & $\begin{array}{l}\text { My family members would } \\
\text { support to save for old age }\end{array}$ & $\begin{array}{l}3.68 \\
0\end{array}$ & $\begin{array}{l}1.06 \\
9\end{array}$ & $\begin{array}{l}3.66 \\
0\end{array}$ & $\begin{array}{l}0.99 \\
9\end{array}$ & 0.127 & 0.899 & No & Accept \\
\hline 7 & $\begin{array}{l}\text { I prefer to live with Spouse } \\
\text { during post retirement period }\end{array}$ & $\begin{array}{l}4.41 \\
0\end{array}$ & $\begin{array}{l}1.03 \\
2\end{array}$ & $\begin{array}{l}4.32 \\
0\end{array}$ & $\begin{array}{l}0.82 \\
4\end{array}$ & 0.528 & 0.598 & No & Accept \\
\hline 8 & $\begin{array}{l}\text { I prefer to live with Children } \\
\text { during post retirement period }\end{array}$ & $\begin{array}{ll}4.22 \\
0\end{array}$ & $\begin{array}{l}0.99 \\
6 \\
\end{array}$ & $\begin{array}{ll}3.94 \\
0\end{array}$ & $\begin{array}{ll}0.84 \\
3\end{array}$ & 0.179 & 0.075 & No & Accept \\
\hline 9 & $\begin{array}{l}\text { I prefer to live with relative } \\
\text { during post retirement period }\end{array}$ & $\begin{array}{l}2.72 \\
0 \\
\end{array}$ & $\begin{array}{l}1.19 \\
8\end{array}$ & $\begin{array}{l}2.90 \\
0 \\
\end{array}$ & $\begin{array}{l}1.24 \\
4 \\
\end{array}$ & 0.902 & 0.369 & No & Accept \\
\hline 10 & $\begin{array}{l}\text { I prefer to live in Old age home } \\
\text { during post retirement period }\end{array}$ & $\begin{array}{l}1.91 \\
0\end{array}$ & $\begin{array}{l}1.15 \\
7\end{array}$ & $\begin{array}{l}2.17 \\
0\end{array}$ & $\begin{array}{l}1.23 \\
0\end{array}$ & 1.321 & 0.188 & No & Accept \\
\hline
\end{tabular}

Source: Primary Data

Interpretation: $\mathrm{t}$-test statistics was applied for the finding the relationship of gender and social security for the statement "Number of persons in my family other than me save for old age", it has been found that the significant $\mathrm{p}$ value for this statement is 0.002 less than 0.05 (at 5 percent significance level). It is significantly difference between male and female. Therefore, the null hypothesis is not accepted. finding the relationship of gender and social security for the statement "Percentage of saving that I do from annual income for old age", it has been found that the significant $\mathrm{p}$ value for this statement is 0.077 greater than 0.05 (at 5 percent significance level). It is not significantly difference between male and female. Therefore, the null hypothesis is accepted. finding the relationship of gender and social security for the statement "I feel socially secure 
with working/employment status of spouse", it has been found that the significant $\mathrm{p}$ value for this statement is 0.961 greater than 0.05 (at 5 percent significance level). It is not significantly difference between male and female. Therefore, the null hypothesis is accepted. finding the relationship of gender and social security for the statement "I have enough property for the survival in old age", it has been found that the significant $\mathrm{p}$ value for this statement is 0.281 greater than 0.05 (at 5 percent significance level). It is not significantly difference between male and female. Therefore, the null hypothesis is accepted. Finding the relationship of gender and social security for the statement "My family members would help during post retirement period", it has been found that the significant $\mathrm{p}$ value for this statement is 0.198 greater than 0.05 (at 5 percent significance level). It is not significantly difference between male and female. Therefore, the null hypothesis is accepted. Finding the relationship of gender and social security for the statement "My family members would support to save for old age", it has been found that the significant $\mathrm{p}$ value for this statement is 0.899 greater than 0.05 (at 5 percent significance level). It is not significantly difference between male and female.
Therefore, the null hypothesis is accepted. Finding the relationship of gender and social security for the statement "I prefer to live with Spouse during post retirement period", it has been found that the significant $\mathrm{p}$ value for this statement is 0.589 greater than 0.05 (at 5 percent significance level). It is not significantly difference between male and female. Therefore, the null hypothesis is accepted.Finding the relationship of gender and social security for the statement "I prefer to live with children during post retirement period", it has been found that the significant $\mathrm{p}$ value for this statement is 0.075 greater than 0.05 (at 5 percent significance level). It is not significantly difference between male and female. Therefore, the null hypothesis is accepted. Finding the relationship of gender and social security for the statement "I prefer to live with relatives during post retirement period", it has been found that the significant $p$ value for this statement is 0.369 greater than 0.05 (at 5 percent significance level). It is not significantly difference between male and female. Therefore, the null hypothesis is accepted. Finding the relationship of gender and social security for the statement "I prefer to live in old age home during post retirement period", it has been found that the significant $\mathrm{p}$ value for this statement is 0.188 greater than 0.05 (at 5 percent significance level). It is not significantly difference between male and female. Therefore, the null hypothesis is accepted.

Table 3: ANOVA Statistics for Age to Social Security Conditions of Salaried Class Investors

\begin{tabular}{|l|l|l|l|l|l|l|l|l|}
\hline \multicolumn{1}{|c|}{ Vest } & $\begin{array}{c}\text { Levene. } \\
\text { Stat. }\end{array}$ & $\begin{array}{c}\text { Sig. } \\
\mathbf{2} \\
\text { tailed) }\end{array}$ & $\begin{array}{c}\text { F- } \\
\text { Value }\end{array}$ & $\begin{array}{c}\text { Sig. } \\
\mathbf{2} \\
\text { tailed) }\end{array}$ & $\begin{array}{c}\text { Welch } \\
\text { Stat. }\end{array}$ & $\begin{array}{c}\text { Sig. } \\
\mathbf{2} \\
\text { tailed) }\end{array}$ & $\begin{array}{l}\text { Stat. } \\
\text { Sig. } \\
\text { (Yes } \\
\text { /No) }\end{array}$ & $\begin{array}{l}\text { Accepted/ } \\
\text { Not Accepted }\end{array}$ \\
\hline $\begin{array}{l}\text { Number of persons in my } \\
\text { family other than me save for } \\
\text { old age }\end{array}$ & 3.766 & .006 & N.A. & N.A. & 4.254 & 0.013 & Yes & Not Accepted \\
\hline $\begin{array}{l}\text { Percentage of saving that I do } \\
\text { from annual income for old } \\
\text { age }\end{array}$ & 2.693 & 0.033 & N.A. & N.A. & 3.047 & 0.045 & Yes & Not Accepted \\
\hline $\begin{array}{l}\text { I feel socially secure with } \\
\text { working/employment status of } \\
\text { spouse }\end{array}$ & 1.025 & 0.397 & 0.831 & 0.507 & N.A. & N.A. & No & Accepted \\
\hline $\begin{array}{l}\text { I have enough property for the } \\
\text { survival in old age }\end{array}$ & 0.745 & 0.563 & 4.712 & .001 & N.A. & N.A. & Yes & No Accepted \\
\hline $\begin{array}{l}\text { My family members would } \\
\text { help during post retirement } \\
\text { period }\end{array}$ & 3.142 & 0.016 & N.A. & N.A. & 4.507 & .009 & Yes & Not Accepted \\
\hline $\begin{array}{l}\text { My family members would } \\
\text { support to save for old age }\end{array}$ & 2.643 & 0.036 & N.A. & N.A. & 4.460 & .009 & Yes & Not Accepted \\
\hline I prefer to live with Spouse & 1.026 & 0.396 & 5.273 & 0.199 & N.A. & N.A. & No & Accepted \\
\hline
\end{tabular}




\begin{tabular}{|l|l|l|l|l|l|l|l|l|}
\cline { 2 - 8 } during post retirement period & & & & & & & & \\
\hline $\begin{array}{l}\text { I prefer to live with Children } \\
\text { during post retirement period }\end{array}$ & 1.576 & 0.184 & 0.255 & 0.906 & N.A. & N.A. & No & Accepted \\
\hline $\begin{array}{l}\text { I prefer to live with relative } \\
\text { during post retirement period }\end{array}$ & 1.790 & 0.134 & 1.969 & 0.102 & N.A. & N.A. & No & Accepted \\
\hline $\begin{array}{l}\text { I prefer to live in Old age } \\
\text { home during post retirement } \\
\text { period }\end{array}$ & 2.384 & 0.054 & 1.995 & 0.098 & N.A. & N.A. & No & Accepted \\
\hline
\end{tabular}

\section{Source: Primary Data}

Interpretation: ANOVA statistics was applied for the finding the relationship of age and social security for the statement "Number of persons in my family other than me save for old age", it has been found that the significant $\mathrm{p}$ value for this statement is 0.013 less than 0.05 (at 5 percent significance level). It is significantly difference among various age groups. Therefore, the null hypothesis is not accepted. Finding the relationship of age and social security for the statement "Percentage of saving that I do from annual income for old age", it has been found that the significant $p$ value for this statement is 0.045 less than 0.05 (at 5 percent significance level). It is significantly difference among various age groups. Therefore, the null hypothesis is not accepted. Finding the relationship of age and social security for the statement "I feel socially secure with working/employment status of spouse", it has been found that the significant $\mathrm{p}$ value for this statement is 0.507 greater than 0.05 (at 5 percent significance level). It is not significantly difference among various age groups. Therefore, the null hypothesis is accepted. Finding the relationship of age and social security for the statement "I have enough property for the survival in old age", it has been found that the significant $\mathrm{p}$ value for this statement is 0.001 less than 0.05 (at 5 percent significance level). It is significantly difference among various age groups. Therefore, the null hypothesis is not accepted. Finding the relationship of age and social security for the statement "My family members would help during post retirement period", it has been found that the significant $p$ value for this statement is 0.009 less than 0.05 (at 5 percent significance level). It is significantly difference among various age groups. Therefore, the null hypothesis is not accepted. Finding the relationship of age and social security for the statement "My family members would support to save for old age", it has been found that the significant $\mathrm{p}$ value for this statement is 0.009 less than 0.05 (at 5 percent significance level). It is significantly difference among various age groups. Therefore, the null hypothesis is not accepted. Finding the relationship of age and social security for the statement "I prefer to live with Spouse during post retirement period", it has been found that the significant $\mathrm{p}$ value for this statement is 0.199 greater than 0.05 (at 5 percent significance level). It is not significantly difference among various age groups. Therefore, the null hypothesis is accepted. Finding the relationship of age and social security for the statement "I prefer to live with children during post retirement period", it has been found that the significant $\mathrm{p}$ value for this statement is 0.906 greater than 0.05 (at 5 percent significance level). It is not significantly difference among various age groups. Therefore, the null hypothesis is accepted. Finding the relationship of age and social security for the statement "I prefer to live with relatives during post retirement period", it has been found that the significant $p$ value for this statement is 0.102 greater than 0.05 (at 5 percent significance level). It is not significantly among various age groups. Therefore, the null hypothesis is accepted. Finding the relationship of age and social security for the statement "I prefer to live in old age home during post retirement period", it has been found that the significant $\mathrm{p}$ value for this statement is 0.098 greater than 0.05 (at 5 percent significance level). It is not significantly difference among various age groups. Therefore, the null hypothesis is accepted.

Table 4: t- test Statistics for Marital Status to Social Security Conditions of Salaried Class Investors

\begin{tabular}{|l|l|l|l|l|l|l|l|l|l|}
\hline & & Married & Unmarried & & & & \\
\hline & Variables & Mean & S.D. & Mean & S.D. & $\begin{array}{l}\text { t } \\
\text { Value }\end{array}$ & $\begin{array}{l}\text { P } \\
\text { Value }\end{array}$ & $\begin{array}{l}\text { Stat Sig. } \\
\text { (Yes/No) }\end{array}$ & $\begin{array}{l}\text { Accepted/ } \\
\text { Not } \\
\text { Accepted }\end{array}$ \\
\hline 1 & Number of persons in my & 2.240 & 1.056 & 2.480 & 1.093 & 1.171 & 0.244 & No & Accept \\
\hline
\end{tabular}




\begin{tabular}{|c|c|c|c|c|c|c|c|c|c|}
\hline & $\begin{array}{l}\text { family other than me save } \\
\text { for old age }\end{array}$ & & & & & & & & \\
\hline 2 & $\begin{array}{l}\text { Percentage of saving that I } \\
\text { do from annual income for } \\
\text { old age }\end{array}$ & 2.170 & 1.061 & 2.790 & 1.453 & 2.275 & 0.028 & Yes & $\begin{array}{l}\text { Not } \\
\text { Accepted }\end{array}$ \\
\hline 3 & $\begin{array}{l}\text { I feel socially secure with } \\
\text { working/employment status } \\
\text { of spouse }\end{array}$ & 3.890 & 1.081 & 3.450 & 1.003 & 2.070 & 0.040 & Yes & $\begin{array}{l}\text { Not } \\
\text { Accepted }\end{array}$ \\
\hline 4 & $\begin{array}{l}\text { I have enough property for } \\
\text { the survival in old age }\end{array}$ & 3.020 & 1.129 & 2.790 & 1.053 & 1.044 & 0.298 & No & Accept \\
\hline 5 & $\begin{array}{l}\text { My family members would } \\
\text { help during post retirement } \\
\text { period }\end{array}$ & 3.450 & 1.126 & 3.550 & 0.971 & 0.429 & 0.669 & No & Accept \\
\hline 6 & $\begin{array}{l}\text { My family members would } \\
\text { support to save for old age }\end{array}$ & 3.680 & 1.031 & 3.640 & 1.055 & 0.232 & 0.817 & No & Accept \\
\hline 7 & $\begin{array}{l}\text { I prefer to live with Spouse } \\
\text { during post } \\
\text { period }\end{array}$ & 4.430 & 0.903 & 4.150 & 1.034 & 1.500 & 0.136 & No & Accept \\
\hline 8 & $\begin{array}{lcc}\text { prefer to live } & \text { with } \\
\text { Children } & \text { during } & \text { post } \\
\text { retirement period } & \end{array}$ & 4.090 & 0.961 & 4.090 & 0.843 & 0.029 & 0.977 & No & Accept \\
\hline 9 & $\begin{array}{l}\text { I prefer to live with relative } \\
\text { during post } \\
\text { period }\end{array}$ & 2.760 & 1.222 & 2.970 & 1.212 & 0.869 & 0.386 & No & Accept \\
\hline 10 & $\begin{array}{l}\text { I prefer to live in Old age } \\
\text { home during post } \\
\text { retirement period }\end{array}$ & 1.980 & 1.145 & 2.210 & 1.364 & $-\overline{0}-$ & 0.382 & No & Accept \\
\hline
\end{tabular}

Source: Primary Data

Interpretation: t-test statistics was applied for the finding the relationship of marital status and social security for the statement "Number of persons in my family other than me save for old age", it has been found that the significant $\mathrm{p}$ value for this statement is 0.244 greater than 0.05 (at 5 percent significance level). It is not significantly difference between married and unmarried. Therefore, the null hypothesis is accepted. Finding the relationship of marital status and social security for the statement "Percentage of saving that I do from annual income for old age", it has been found that the significant $\mathrm{p}$ value for this statement is 0.028 less than 0.05 (at 5 percent significance level). It is significantly difference between married and unmarried. Therefore, the null hypothesis is not accepted. Finding the relationship of marital status and social security for the statement "I feel socially secure with working/employment status of spouse", it has been found that the significant $p$ value for this statement is 0.040 less than 0.05 (at 5 percent significance level). It is significantly difference between married and unmarried. Therefore, the null hypothesis is not accepted.
Finding the relationship of marital status and social security for the statement "I have enough property for the survival in old age", it has been found that the significant $\mathrm{p}$ value for this statement is 0.298 greater than 0.05 (at 5 percent significance level). It is not significantly difference between married and unmarried. Therefore, the null hypothesis is accepted. Finding the relationship of marital status and social security for the statement "My family members would help during post retirement period", it has been found that the significant $\mathrm{p}$ value for this statement is 0.669 greater than 0.05 (at 5 percent significance level). It is not significantly difference between married and unmarried. Therefore, the null hypothesis is accepted. Finding the relationship of marital status and social security for the statement "My family members would support to save for old age", it has been found that the significant $\mathrm{p}$ value for this statement is 0.817 greater than 0.05 (at 5 percent significance level). It is not significantly difference between married and unmarried. Therefore, the null hypothesis is accepted. Finding the relationship of marital status and social security for 
the statement "I prefer to live with Spouse during post retirement period", it has been found that the significant $\mathrm{p}$ value for this statement is 0.136 greater than 0.05 (at 5 percent significance level). It is not significantly difference between married and unmarried. Therefore, the null hypothesis is accepted. Finding the relationship of marital status and social security for the statement "I prefer to live with children during post retirement period", it has been found that the significant $\mathrm{p}$ value for this statement is 0.977 greater than 0.05 (at 5 percent significance level). It is not significantly difference between married and unmarried. Therefore, the null hypothesis is accepted. Finding the relationship of marital status and social security for the statement "I prefer to live with relatives during post retirement period", it has been found that the significant $\mathrm{p}$ value for this statement is 0.386 greater than 0.05 (at 5 percent significance level). It is not significantly difference between married and unmarried. Therefore, the null hypothesis is accepted. Finding the relationship of marital status and social security for the statement "I prefer to live in old age home during post retirement period", it has been found that the significant $\mathrm{p}$ value for this statement is 0.382 greater than 0.05 (at 5 percent significance level). It is not significantly difference between married and unmarried. Therefore, the null hypothesis is accepted.

Table 5: t-test Statistics for Nature of Employment to Social Security Conditions of Salaried Class Investors

\begin{tabular}{|c|c|c|c|c|c|c|c|c|c|}
\hline & & Gover & ment & Private & & & & & \\
\hline & Variables & Mean & S.D. & Mean & S.D. & $\begin{array}{l}t \\
\text { Value }\end{array}$ & \begin{tabular}{|l|}
$\mathbf{P}$ \\
Value
\end{tabular} & $\begin{array}{l}\text { Stat Sig. } \\
\text { (Yes/No) }\end{array}$ & $\begin{array}{l}\text { Accepted/ } \\
\text { Not } \\
\text { Accepted }\end{array}$ \\
\hline 1 & $\begin{array}{l}\text { Number of persons in } \\
\text { my family other than } \\
\text { me save for old age }\end{array}$ & 2.370 & 1.076 & 2.000 & 0.983 & 1.697 & 0.092 & No & Accepted \\
\hline 2 & $\begin{array}{l}\text { Percentage of saving } \\
\text { that I do from annual } \\
\text { income for old age }\end{array}$ & 2.310 & 1.242 & 2.300 & 0.915 & 0.034 & 0.973 & No & Accepted \\
\hline 3 & $\begin{array}{l}\text { I feel socially secure } \\
\text { with } \\
\text { working/employment } \\
\text { status of spouse }\end{array}$ & 3.760 & 1.100 & 3.930 & 0.980 & -0.796 & 0.428 & No & Accepted \\
\hline 4 & $\begin{array}{l}\text { I have enough property } \\
\text { for the survival in old } \\
\text { age }\end{array}$ & 2.970 & 1.130 & 2.970 & 1.066 & 0.000 & 1.000 & No & Accepted \\
\hline 5 & $\begin{array}{l}\text { My family members } \\
\text { would help during post } \\
\text { retirement period }\end{array}$ & 3.470 & 1.084 & 3.500 & 1.137 & -0.149 & 0.882 & No & Accepted \\
\hline 6 & $\begin{array}{l}\text { My family members } \\
\text { would support to save } \\
\text { for old age }\end{array}$ & 3.660 & 0.966 & 3.730 & 1.285 & -0.355 & 0.723 & No & Accepted \\
\hline 7 & $\begin{array}{l}\text { I prefer to live with } \\
\text { Spouse during post } \\
\text { retirement period }\end{array}$ & 4.260 & 0.948 & 4.800 & 0.761 & -3.309 & 0.002 & Yes & $\begin{array}{l}\text { Not } \\
\text { Accepted }\end{array}$ \\
\hline 8 & $\begin{array}{l}\text { I prefer to live with } \\
\text { Children during post } \\
\text { retirement period }\end{array}$ & 4.010 & 0.921 & 4.400 & 0.932 & -2.078 & 0.039 & Yes & $\begin{array}{l}\text { Not } \\
\text { Accepted }\end{array}$ \\
\hline
\end{tabular}




\begin{tabular}{|l|l|l|l|l|l|l|l|l|l|}
\hline 9 & $\begin{array}{l}\text { I prefer to live with } \\
\text { relative during post } \\
\text { retirement period }\end{array}$ & 2.810 & 1.169 & 2.800 & 1.424 & 0.030 & 0.976 & No & Accepted \\
\hline 10 & $\begin{array}{l}\text { I prefer to live in Old } \\
\text { age home during post } \\
\text { retirement period }\end{array}$ & 2.080 & 1.217 & 1.870 & 1.106 & 0.853 & 0.395 & No & Accepted \\
\hline
\end{tabular}

Source: Primary Data

Interpretation: $\mathrm{t}$-test statistics was applied for the finding the relationship of nature of employment and social security for the statement "Number of persons in my family other than me save for old age", it has been found that the significant $p$ value for this statement is 0.092 greater than 0.05 (at 5 percent significance level). It is not significantly difference between government and private sector employee. Therefore, the null hypothesis is accepted. Finding the relationship of nature of employment and social security for the statement "Percentage of saving that I do from annual income for old age", it has been found that the significant $\mathrm{p}$ value for this statement is 0.973 greater than 0.05 (at 5 percent significance level). It is not significantly difference between government and private sector employee. Therefore, the null hypothesis is accepted. Finding the relationship of nature of employment and social security for the statement "I feel socially secure with working/employment status of spouse", it has been found that the significant $p$ value for this statement is 0.428 greater than 0.05 (at 5 percent significance level). It is not significantly difference between government and private sector employee. Therefore, the null hypothesis is accepted. Finding the relationship of nature of employment and social security for the statement "I have enough property for the survival in old age", it has been found that the significant $p$ value for this statement is 1.000 greater than 0.05 (at 5 percent significance level). It is not significantly difference between government and private sector employee. Therefore, the null hypothesis is accepted. Finding the relationship of nature of employment and social security for the statement "My family members would help during post retirement period", it has been found that the significant $\mathrm{p}$ value for this statement is 0.882 greater than 0.05 (at 5 percent significance level). It is not significantly difference between government and private sector employee.
Therefore, the null hypothesis is accepted. Finding the relationship of nature of employment and social security for the statement "My family members would support to save for old age", it has been found that the significant $p$ value for this statement is 0.723 greater than 0.05 (at 5 percent significance level). It is not significantly difference between government and private sector employee. Therefore, the null hypothesis is accepted. Finding the relationship of nature of employment and social security for the statement "I prefer to live with Spouse during post retirement period", it has been found that the significant $\mathrm{p}$ value for this statement is 0.002 less than 0.05 (at 5 percent significance level). It is significantly difference between government and private sector employee. Therefore, the null hypothesis is not accepted. Finding the relationship of nature of employment and social security for the statement "I prefer to live with children during post retirement period", it has been found that the significant $p$ value for this statement is 0.039 less than 0.05 (at 5 percent significance level). It is significantly difference between government and private sector employee. Therefore, the null hypothesis is not accepted. Finding the relationship of nature of employment and social security for the statement "I prefer to live with relatives during post retirement period", it has been found that the significant $\mathrm{p}$ value for this statement is 0.976 greater than 0.05 (at 5 percent significance level). It is not significantly difference between government and private sector employee. Therefore, the null hypothesis is accepted. Finding the relationship of nature of employment and social security for the statement "I prefer to live in old age home during post retirement period", it has been found that the significant $\mathrm{p}$ value for this statement is 0.395 greater than 0.05 (at 5 percent significance level). It is not significantly difference between government and private sector employee. Therefore, the null hypothesis is accepted.

Table 6: ANOVA Statistics for Job Experience to Social Security Conditions of Salaried Class Investors

\begin{tabular}{|c|c|c|c|c|c|c|c|l|}
\hline $\begin{array}{c}\text { Test } \\
\text { Variables }\end{array}$ & Levene. & Sig. & $\begin{array}{c}\text { F- } \\
\text { Value }\end{array}$ & Sig. & Welch & Sig. & $\begin{array}{c}\text { Stat. } \\
\text { Sig. }\end{array}$ & Accepted/ \\
\hline
\end{tabular}

www.psycholdgyandeducation.net 


\begin{tabular}{|c|c|c|c|c|c|c|c|c|}
\hline & Stat. & $\begin{array}{c}(2 \\
\text { tailed })\end{array}$ & & $\begin{array}{c}(2 \\
\text { tailed })\end{array}$ & Stat. & $\begin{array}{c}(2 \\
\text { tailed })\end{array}$ & $\begin{array}{l}\text { (Yes } \\
\text { /No) }\end{array}$ & $\begin{array}{l}\text { Not } \\
\text { Accepted }\end{array}$ \\
\hline $\begin{array}{l}\text { Number of persons in } \\
\text { my family other than } \\
\text { me save for old age }\end{array}$ & 1.744 & 0.143 & 2.272 & 0.064 & N.A. & N.A. & No & Accepted \\
\hline $\begin{array}{l}\text { Percentage of saving } \\
\text { that I do from annual } \\
\text { income for old age }\end{array}$ & 3.575 & 0.008 & N.A. & N.A. & 2.241 & 0.111 & No & Accepted \\
\hline $\begin{array}{l}\text { I feel socially secure } \\
\text { with } \\
\text { working/employment } \\
\text { status of spouse }\end{array}$ & 1.062 & 0.377 & 0.467 & 0.760 & N.A. & N.A. & No & Accepted \\
\hline $\begin{array}{l}\text { I have enough property } \\
\text { for the survival in old } \\
\text { age }\end{array}$ & 1.030 & 0.394 & 2.869 & 0.025 & N.A. & N.A. & Yes & $\begin{array}{l}\text { Not } \\
\text { Accepted }\end{array}$ \\
\hline $\begin{array}{l}\text { My family members } \\
\text { would help during post } \\
\text { retirement period }\end{array}$ & 1.465 & 0.216 & 1.259 & 0.289 & N.A. & N.A. & No & Accepted \\
\hline $\begin{array}{l}\text { My family members } \\
\text { would support to save } \\
\text { for old age }\end{array}$ & 3.294 & 0.013 & N.A. & N.A. & 1.108 & 0.384 & $\mathrm{No}$ & Accepted \\
\hline $\begin{array}{l}\text { I prefer to live with } \\
\text { Spouse during post } \\
\text { retirement period }\end{array}$ & 1.885 & 0.116 & 3.352 & 0.012 & N.A. & N.A. & Yes & $\begin{array}{l}\text { Not } \\
\text { Accepted }\end{array}$ \\
\hline $\begin{array}{l}\text { I prefer to live with } \\
\text { Children during post } \\
\text { retirement period }\end{array}$ & 0.194 & 0.941 & 0,149 & 0,963 & N.A. & N.A. & No & Accepted \\
\hline $\begin{array}{l}\text { I prefer to live with } \\
\text { relative during post } \\
\text { retirement period }\end{array}$ & 0.550 & 0.699 & 1.403 & 0.236 & N.A. & N.A. & No & Accepted \\
\hline $\begin{array}{l}\text { I prefer to live in Old } \\
\text { age home during post } \\
\text { retirement period }\end{array}$ & 2.415 & 0.052 & 0.871 & 0.483 & N.A. & N.A. & No & Accepted \\
\hline
\end{tabular}

\section{Source: Primary Data}

Interpretation: ANOVA statistics was applied for the finding the relationship of job experience and social security for the statement "Number of persons in my family other than me save for old age", it has been found that the significant $p$ value for this statement is 0.064 greater than 0.05 (at 5 percent significance level). It is not significantly difference among various groups of experience of job. Therefore, the null hypothesis is accepted. Finding the relationship of job experience and social security for the statement "Percentage of saving that I do from annual income for old age", it has been found that the significant $\mathrm{p}$ value for this statement is 0.111 greater than 0.05 (at 5 percent significance level). It is not significantly difference among various groups of experience of job. Therefore, the null hypothesis is accepted. Finding the relationship of job experience and social security for the statement "I feel socially secure with working/employment status of spouse", it has been found that the significant $p$ value for this statement is 0.760 greater than 0.05 (at 5 percent significance level). It is not significantly difference among various groups of experience of job. Therefore, the null hypothesis is accepted. Finding the relationship of job experience and social security for the statement "I have enough property for the survival in old age", it has been found that the significant $p$ value for this statement is 0.025 less than 0.05 (at 5 percent 
significance level). It is significantly difference among various groups of experience of job. Therefore, the null hypothesis is not accepted. Finding the relationship of job experience and social security for the statement "My family members would help during post retirement period", it has been found that the significant $\mathrm{p}$ value for this statement is 0.289 greater than 0.05 (at 5 percent significance level). It is not significantly difference among various groups of experience of job. Therefore, the null hypothesis is accepted. Finding the relationship of job experience and social security for the statement "My family members would support to save for old age", it has been found that the significant $\mathrm{p}$ value for this statement is 0.384 greater than 0.05 (at 5 percent significance level). It is not significantly difference among various groups of experience of job. Therefore, the null hypothesis is accepted. Finding the relationship of job experience and social security for the statement "I prefer to live with Spouse during post retirement period", it has been found that the significant $p$ value for this statement is 0.012 less than 0.05 (at 5 percent significance level). It is significantly difference among various groups of experience of job. Therefore, the null hypothesis is not accepted. Finding the relationship of job experience and social security for the statement "I prefer to live with children during post retirement period", it has been found that the significant $\mathrm{p}$ value for this statement is 0.963 greater than 0.05 (at 5 percent significance level). It is not significantly difference among various groups of experience of job. Therefore, the null hypothesis is accepted. Finding the relationship of job experience and social security for the statement "I prefer to live with relatives during post retirement period", it has been found that the significant $p$ value for this statement is 0.236 greater than 0.05 (at 5 percent significance level). It is not significantly difference among various groups of experience of job. Therefore, the null hypothesis is accepted. Finding the relationship of job experience and social security for the statement "I prefer to live in old age home during post retirement period", it has been found that the significant $\mathrm{p}$ value for this statement is 0.483 greater than 0.05 (at 5 percent significance level). It is not significantly difference among various groups of experience of job. Therefore, the null hypothesis is accepted.

Table 7: ANOVA Statistics for Annual Income to Social Security Conditions of Salaried Class Investors

\begin{tabular}{|l|l|l|l|l|l|l|l|l|}
\hline \multicolumn{1}{|c|}{ Vest } & $\begin{array}{c}\text { Levene. } \\
\text { Stat. }\end{array}$ & $\begin{array}{c}\text { Sig. } \\
\mathbf{2} \\
\text { tailed) }\end{array}$ & $\begin{array}{c}\text { F- } \\
\text { Value }\end{array}$ & $\begin{array}{c}\text { Sig. } \\
\mathbf{2} \\
\text { tailed) }\end{array}$ & $\begin{array}{l}\text { Welch } \\
\text { Stat. }\end{array}$ & $\begin{array}{c}\text { Sig. } \\
\mathbf{2} \\
\text { tailed) }\end{array}$ & $\begin{array}{l}\text { Stat. } \\
\text { Sig. } \\
\text { (Yes } \\
\text { /No) }\end{array}$ & $\begin{array}{l}\text { Accepted/ } \\
\text { Not } \\
\text { Accepted }\end{array}$ \\
\hline $\begin{array}{l}\text { Number of persons } \\
\text { in my family other } \\
\text { than me save for old } \\
\text { age }\end{array}$ & 2.497 & 0.054 & 0.363 & 0.835 & N.A. & N.A. & No & Accepted \\
\hline $\begin{array}{l}\text { Percentage of saving } \\
\text { that I do from annual } \\
\text { income for old age }\end{array}$ & 2.312 & 0.060 & 5.006 & 0.001 & N.A. & N.A. & Yes & $\begin{array}{l}\text { Not } \\
\text { Accepted }\end{array}$ \\
\hline $\begin{array}{l}\text { I feel socially secure } \\
\text { with } \\
\text { working/employment } \\
\text { status of spouse }\end{array}$ & 0.441 & 0.779 & 1.891 & 0.115 & N.A. & N.A. & No & Accepted \\
\hline $\begin{array}{l}\text { I have enough } \\
\text { property for the } \\
\text { survival in old age }\end{array}$ & 2.313 & 0.060 & 1.610 & 0.175 & N.A. & N.A. & No & Accepted \\
\hline $\begin{array}{l}\text { My family members } \\
\text { would help during } \\
\text { post retirement } \\
\text { period }\end{array}$ & 2.183 & 0.074 & 2.013 & 0.096 & N.A. & N.A. & No & Accepted \\
\hline $\begin{array}{l}\text { My family members } \\
\text { would support to } \\
\text { save for old age }\end{array}$ & 0.811 & 0.520 & 1.695 & 0.154 & N.A. & N.A. & No & Accepted \\
\hline
\end{tabular}




\begin{tabular}{|l|l|l|l|l|l|l|l|l|}
\cline { 2 - 8 } $\begin{array}{l}\text { I prefer to live with } \\
\text { Spouse during post } \\
\text { retirement period }\end{array}$ & 0.273 & 0.895 & 1.945 & 0.106 & N.A. & N.A. & No & Accepted \\
\hline $\begin{array}{l}\text { I prefer to live with } \\
\text { Children during post } \\
\text { retirement period }\end{array}$ & 0.466 & 0.760 & 3.665 & 0.007 & N.A. & N.A. & Yes & $\begin{array}{l}\text { Not } \\
\text { Accepted }\end{array}$ \\
\hline $\begin{array}{l}\text { I prefer to live with } \\
\text { relative during post } \\
\text { retirement period }\end{array}$ & 2.620 & 0.037 & N.A. & N.A. & 0.574 & 0.689 & No & Accepted \\
\hline $\begin{array}{l}\text { I prefer to live in Old } \\
\text { age home during } \\
\text { post } \\
\text { period retirement }\end{array}$ & 2.195 & 0.072 & 2.411 & 0.052 & N.A. & N.A. & No & Accepted \\
\hline
\end{tabular}

Source: Primary Data

Interpretation: ANOVA statistics was applied for the finding the relationship of annual income and social security for the statement "Number of persons in my family other than me save for old age", it has been found that the significant $p$ value for this statement is 0.835 greater than 0.05 (at 5 percent significance level). It is not significantly difference among groups of various income level. Therefore, the null hypothesis is accepted. Finding the relationship of annual income and social security for the statement "Percentage of saving that I do from annual income for old age", it has been found that the significant $\mathrm{p}$ value for this statement is 0.001 less than 0.05 (at 5 percent significance level). It is significantly difference among groups of various income level. Therefore, the null hypothesis is not accepted. Finding the relationship of annual income and social security for the statement "I feel socially secure with working/employment status of spouse", it has been found that the significant $p$ value for this statement is 0.115 greater than 0.05 (at 5 percent significance level). It is not significantly difference among groups of various income level. Therefore, the null hypothesis is accepted. Finding the relationship of annual income and social security for the statement "I have enough property for the survival in old age", it has been found that the significant $p$ value for this statement is 0.175 greater than 0.05 (at 5 percent significance level). It is not significantly difference among groups of various income level. Therefore, the null hypothesis is accepted. Finding the relationship of annual income and social security for the statement "My family members would help during post retirement period", it has been found that the significant $\mathrm{p}$ value for this statement is 0.096 greater than 0.05 (at 5 percent significance level). It is not significantly difference among groups of various income level. Therefore, the null hypothesis is accepted. Finding the relationship of annual income and social security for the statement "My family members would support to save for old age", it has been found that the significant $\mathrm{p}$ value for this statement is 0.154 greater than 0.05 (at 5 percent significance level). It is not significantly difference among groups of various income level. Therefore, the null hypothesis is accepted. Finding the relationship of annual income and social security for the statement "I prefer to live with Spouse during post retirement period", it has been found that the significant $\mathrm{p}$ value for this statement is 0.106 greater than 0.05 (at 5 percent significance level). It is not significantly difference among groups of various income level. Therefore, the null hypothesis is accepted. Finding the relationship of annual income and social security for the statement "I prefer to live with children during post retirement period", it has been found that the significant $p$ value for this statement is 0.007 less than 0.05 (at 5 percent significance level). It is significantly difference among groups of various income level. Therefore, the null hypothesis is not accepted. Finding the relationship of annual income and social security for the statement "I prefer to live with relatives during post retirement period", it has been found that the significant $\mathrm{p}$ value for this statement is 0.689 greater than 0.05 (at 5 percent significance level). It is not significantly difference among groups of various income level. Therefore, the null hypothesis is accepted. Finding the relationship of annual income and social security for the statement "I prefer to live in old age home during post retirement period", it has been found 
that the significant $\mathrm{p}$ value for this statement is 0.052 greater than 0.05 (at 5 percent significance level). It is not significantly difference among groups of various income level. Therefore, the null hypothesis is accepted.

Table 8: ANOVA Statistics for Number of Dependent Family members to Social Security Conditions of Salaried Class Investors

\begin{tabular}{|c|c|c|c|c|c|c|c|c|}
\hline $\begin{array}{c}\text { Test } \\
\text { Variables }\end{array}$ & $\begin{array}{l}\text { Levene. } \\
\text { Stat. }\end{array}$ & $\begin{array}{c}\text { Sig. } \\
(2 \\
\text { tailed })\end{array}$ & $\begin{array}{c}\text { F- } \\
\text { Value }\end{array}$ & $\begin{array}{l}\text { Sig. } \\
(2 \\
\text { tailed })\end{array}$ & $\begin{array}{l}\text { Welch } \\
\text { Stat. }\end{array}$ & $\begin{array}{l}\text { Sig. } \\
(2 \\
\text { tailed })\end{array}$ & $\begin{array}{l}\text { Stat. } \\
\text { Sig. } \\
\text { (Yes } \\
\text { /No) }\end{array}$ & $\begin{array}{l}\text { Accepted/ } \\
\text { Not } \\
\text { Accepted }\end{array}$ \\
\hline $\begin{array}{l}\text { Number of persons } \\
\text { in my family other } \\
\text { than me save for old } \\
\text { age }\end{array}$ & 3.187 & 0.015 & N.A. & N.A. & 0.680 & 0.609 & No & Accepted \\
\hline $\begin{array}{l}\text { Percentage of saving } \\
\text { that I do from annual } \\
\text { income for old age }\end{array}$ & 1.306 & 0.270 & 0.903 & 0.464 & N.A. & N.A. & No & Accepted \\
\hline $\begin{array}{l}\text { I feel socially secure } \\
\text { with } \\
\text { working/employment } \\
\text { status of spouse }\end{array}$ & 1.186 & 0.319 & 0.871 & 0.483 & N.A. & N.A. & No & Accepted \\
\hline $\begin{array}{l}\text { I have enough } \\
\text { property for the } \\
\text { survival in old age }\end{array}$ & 0.988 & 0.416 & 2.501 & 0.045 & N.A. & N.A. & Yes & $\begin{array}{l}\text { Not } \\
\text { Accepted }\end{array}$ \\
\hline \begin{tabular}{lrr}
\multicolumn{3}{|c|}{ My family members } \\
would & help during \\
post retirement & retiod
\end{tabular} & 3.328 & 0.012 & N.A. & N.A. & 1.169 & 0.336 & No & Accepted \\
\hline $\begin{array}{l}\text { My family members } \\
\text { would support to } \\
\text { save for old age }\end{array}$ & 4.345 & 0.002 & N.A. & N.A. & 0.751 & 0.562 & No & Accepted \\
\hline $\begin{array}{l}\text { I prefer to live with } \\
\text { Spouse during post } \\
\text { retirement period }\end{array}$ & 4.199 & 0.003 & N.A. & N.A. & 1.057 & 0.387 & No & Accepted \\
\hline $\begin{array}{l}\text { I prefer to live with } \\
\text { Children during post } \\
\text { retirement period }\end{array}$ & 3.556 & 0.008 & N.A. & N.A. & 1.114 & 0.360 & No & Accepted \\
\hline $\begin{array}{l}\text { I prefer to live with } \\
\text { relative during post } \\
\text { retirement period }\end{array}$ & 0.528 & 0.715 & 0.634 & 0.639 & N.A. & N.A. & No & Accepted \\
\hline 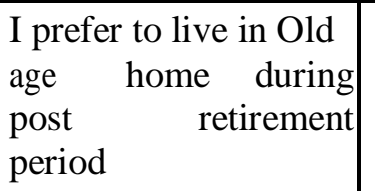 & 0.247 & 0.911 & 0.625 & 0.645 & N.A. & N.A. & No & Accepted \\
\hline
\end{tabular}

Source: Primary Data 
Interpretation: ANOVA statistics was applied for the finding the relationship of dependent family members and social security for the statement "Number of persons in my family other than me save for old age", it has been found that the significant $\mathrm{p}$ value for this statement is 0.609 greater than 0.05 (at 5 percent significance level). It is not significantly difference between among various groups of dependent family members. Therefore, the null hypothesis is accepted. Finding the relationship of dependent family members and social security for the statement "Percentage of saving that I do from annual income for old age", it has been found that the significant $\mathrm{p}$ value for this statement is 0.464 greater than 0.05 (at 5 percent significance level). It is not significantly difference among various groups of dependent family members. Therefore, the null hypothesis is accepted. Finding the relationship of dependent family members and social security for the statement "I feel socially secure with working/employment status of spouse", it has been found that the significant $p$ value for this statement is 0.483 greater than 0.05 (at 5 percent significance level). It is not significantly difference among various groups of dependent family members. Therefore, the null hypothesis is accepted. Finding the relationship of dependent family members and social security for the statement "I have enough property for the survival in old age", it has been found that the significant $p$ value for this statement is 0.045 less than 0.05 (at 5 percent significance level). It is significantly difference among various groups of dependent family members. Therefore, the null hypothesis is no accepted. Finding the relationship of dependent family members and social security for the statement "My family members would help during post retirement period", it has been found that the significant $p$ value for this statement is 0.366 greater than 0.05 (at 5 percent significance level). It is not significantly difference among various groups of dependent family members. Therefore, the null hypothesis is accepted. Finding the relationship of dependent family members and social security for the statement "My family members would support to save for old age", it has been found that the significant $\mathrm{p}$ value for this statement is 0.562 greater than 0.05 (at 5 percent significance level). It is not significantly difference among various groups of dependent family members. Therefore, the null hypothesis is accepted. Finding the relationship of dependent family members and social security for the statement "I prefer to live with Spouse during post retirement period", it has been found that the significant $\mathrm{p}$ value for this statement is 0.387 greater than 0.05 (at 5 percent significance level). It is not significantly difference among various groups of dependent family members. Therefore, the null hypothesis is accepted. Finding the relationship of dependent family members and social security for the statement "I prefer to live with children during post retirement period", it has been found that the significant $\mathrm{p}$ value for this statement is 0.360 greater than 0.05 (at 5 percent significance level). It is not significantly difference among various groups of dependent family members. Therefore, the null hypothesis is accepted. Finding the relationship of dependent family members and social security for the statement "I prefer to live with relatives during post retirement period", it has been found that the significant $p$ value for this statement is 0.639 greater than 0.05 (at 5 percent significance level). It is not significantly difference among various groups of dependent family members. Therefore, the null hypothesis is accepted. Finding the relationship of dependent family members and social security for the statement "I prefer to live in old age home during post retirement period", it has been found that the significant $\mathrm{p}$ value for this statement is 0.645 greater than 0.05 (at 5 percent significance level). It is not significantly difference among various groups of dependent family members. Therefore, the null hypothesis is accepted.

\section{Conclusion and findings:}

This paper concluded that Social security is very necessary for the welfare of the entire society. Some pension plans are operating by the government to provide the social and economic security to its employees and their family like old pension scheme and new pension scheme. Main finding of this paper is demographical variables like gender, age, marital status, nature of employment, job experience, annual income, number of dependent family members are associated with the social security conditions. There is no significant relation difference between male and female regarding the social security conditions except "number of persons in my family other than me save for old age". On the basis of age, there is significant difference among various age groups and not significant difference on the basis of marital status, there is no significant difference between married and 
unmarried persons for the social security conditions they have same socially secure except the "percentage of saving from annual income for old age" and "feel socially secure with working status of spouse". Government and private sector employees have same social security conditions except "prefer to live with spouse" and "prefer to live with children". There is no significant difference among various groups of job experience. They have same social security conditions except they have enough property and proper to live with spouse in old age. On the basis of annual income, all the respondents have same social security conditions except percentage of saving for old age and they prefer to live children in old age. All the respondents have same social security conditions except they have enough property for old age survival on the basis of number of dependent family members. Almost all the salaried class investors have same level of social security conditions on different demographical variables except on some statements.

\section{References:}

- Barrientos, A., (2012). What is the Role of Social Pensions in Asia, ADBI Working Paper Series No. 351, Asian Development Bank Institute?

- Bloom, D. E., Canning, D., Mansfield, R. K., \& Moore, M. (2007). Demographic change, social security systems, and savings. Journal of Monetary Economics, 54(1), 92-114.

- Bloom, D. E., Mahal, A., Rosenberg, L., \& Sevilla, J. (2010). Economic security arrangements in the context of population ageing in India. International Social Security Review, 63(3-4), 59-89.

- Chatterjee, S. (2010). Retirement savings of private and public sector employees: A comparative study. Journal of Applied Business Research (JABR), 26(6).

- Chaudhuri, A., \& Roy, K. (2009). Gender differences in living arrangements among older persons in India. Journal of Asian and African Studies, 44(3), 259-277.

- Ketkaew, C., Van Wouwe, M., Vichitthamaros, P., \& Teerawanviwat, D. (2019). The effect of expected income on wealth accumulation and retirement contribution of Thai wageworkers. SAGE Open, 9(4).

- Haris, A., \& Said, R. (2012). Social security wealth and early retirement in public pension scheme. International Journal of Economics and Management, 6(2), 346-359.
- Mansor, M. F., Chor, C. H., Abu, N. H., \& Shaari, M. S. (2015). Demographic factors associated with retirement planning: a study of employees in Malaysian Health Sectors. Asian Social Science, 11(13), 108-116.

- Manoli, D. S., \& Weber, A. (2016). The effects of the early retirement age on retirement decisions (No. w22561). National Bureau of Economic Research.

- Pandiyan, L., \& Aranganathan, T. (2012). Savings and Investments Attitude of Salaried Class in Cuddalore District. IOSR Journal of Business and Management, 1(1), 40-49.

- Patel, C. Y. P., \& Patel, C. C. Y. (2012). A study of investment perspective of salaried people (private sector). Asia Pacific Journal of Marketing \& Management Review, 1(2), 126-146.

- Salvador, R., (2012). An Analysis of Future Retirees' Concerns regarding Pension Plans

Reforms and Demographic Factors that Influence Retirement Investment Decisions, North Central University, Arizona.

- Shendkar, D. B., (2016). Study of Financial Planning for Retirement amongst Individuals in select age group of 25 years to 45 years in Pune city, Tilak Maharashtra Vidhyapeeth, Pune.

- Singh, C., Bharati, K., \& Sanyal, A. (2015). Ageing in India: Need for Universal Pension Scheme. Economic and Political Weekly, 40-46.

- Sood, D., \& Kaur, N. (2015). A study of saving and investment pattern of salaried class people with special reference to chandigarh (India). International Journal of Research in Engineering, IT \& Social Sciences, 5(2), 1-15.

- Swasdpeera, P., \& Pandey, I. M. (2012). Determinants of personal saving: a study of salaried individuals in Thailand. Afro-Asian Journal of Finance and Accounting, 3(1), 34-68.

- Thakur, S. S., \& Jain, S. C. (2017). Retirement planning and social security concept in Indian context. Intern J Comm Manage Res, 3(2), 35-40. 